
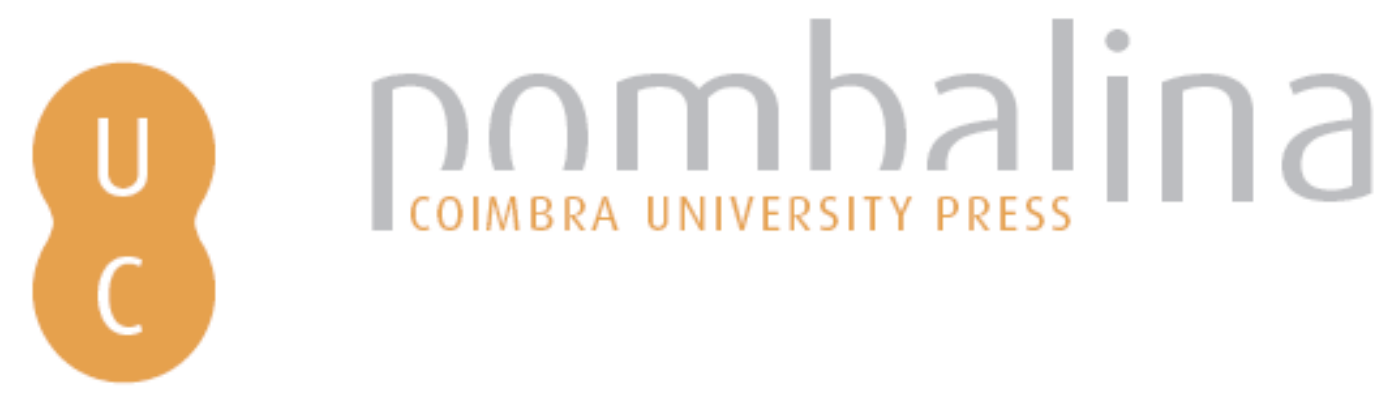

\title{
Characteristics of youth sport participants and non-participants in Mexico City
}

$\begin{array}{ll}\text { Autor(es): } & \text { Siegel, Shannon R.; Cumming, Sean P.; Peña Reyes, Maria Eugenia; } \\ \text { Cárdenas Barahona, Eyra E.; Malina, Robert M. }\end{array}$

Publicado por: Imprensa da Universidade de Coimbra

URL

persistente: URI:http://hdl.handle.net/10316.2/38559

DOI: $\quad$ DOI:http://dx.doi.org/10.14195/978-989-26-0773-3_18

Accessed : $\quad$ 26-Apr-2023 13:42:03

A navegação consulta e descarregamento dos títulos inseridos nas Bibliotecas Digitais UC Digitalis, UC Pombalina e UC Impactum, pressupõem a aceitação plena e sem reservas dos Termos e Condições de Uso destas Bibliotecas Digitais, disponíveis em https://digitalis.uc.pt/pt-pt/termos.

Conforme exposto nos referidos Termos e Condições de Uso, o descarregamento de títulos de acesso restrito requer uma licença válida de autorização devendo o utilizador aceder ao(s) documento(s) a partir de um endereço de IP da instituição detentora da supramencionada licença.

Ao utilizador é apenas permitido o descarregamento para uso pessoal, pelo que o emprego do(s) título(s) descarregado(s) para outro fim, designadamente comercial, carece de autorização do respetivo autor ou editor da obra.

Na medida em que todas as obras da UC Digitalis se encontram protegidas pelo Código do Direito de Autor e Direitos Conexos e demais legislação aplicável, toda a cópia, parcial ou total, deste documento, nos casos em que é legalmente admitida, deverá conter ou fazer-se acompanhar por este aviso.

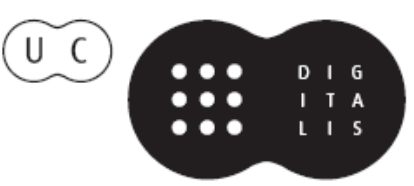




\section{GROWTH AND \\ MATURATION \\ IN HUMAN BIOLOGY \\ AND SPORTS}

FESTSCHRIFT HONORING ROBERT M. MALINA

BY FELLOWS AND COLLEAGUES

PETER TODD KATZMARZYK MANUEL J COELHO E SILVA

EDITORS 


\title{
CHARACTERISTICS OF YOUTH SPORT PARTICIPANTS AND NON-PARTICIPANTS IN MEXICO CITY
}

\author{
Shannon R. Siegel \\ Sean P. Cumming, \\ Maria Eugenia Peña Reyes \\ Eyra E. Cárdenas Barahona \\ Robert M. Malina
}

\section{INTRODUCTION}

Sport is a primary context for physical activity for youth and has high social value in many societies. Given the media's overwhelming interest in youth competing in sports at national and international levels, it is not surprising that the important role that organized sport plays in the health and development of children and adolescents is often overlooked. The highly talented are a very visible minority whereas the overwhelming majority of youth who participate and never attain elite levels often pass under the radar (Malina, 2009). This is of particular concern since only a small percentage of youth will ever play sports at a professional or international level, whereas the majority of youth can benefit physically and psychologically from participating in sports (Malina, 2008).

A consequence of our preoccupation with elite young athletes is that relatively more is known about elite young athletes in contrast to youth sports participants in general. This is especially apparent in the literature dealing with the physical growth and biological maturation of young athletes (Malina et al., 2004). The literature on sportrelated injuries in youth often includes both the general participant and the elite (Malina, $200 \mathrm{Ia}$ ). In contrast, the literature on overuse injuries and burnout is generally concentrated on the elite (Weinberg and Gould, 20 I 0; Gould and Dieffenbach, 2003).

The literature dealing with characteristics of the general population of youth sports participants, in contrast, is less extensive and uneven. Although considerable discussion of psychosocial outcomes associated with participation in youth sports exists, a good deal of the literature deals with social influences. Social influences include parents, coaches, and peers - in contrast to the psychosocial characteristics of participants and the influence of sport on aspects of psychosocial development such as self-concept and selfesteem, perceived competence in sport and social interactions, peer interactions, parentchild and coach-child relationships, values of fair play, and so on. 
A motivational theory that has received much attention in the context of competitive youth sports is Achievement Goal Theory (Nicholls, 1984). This theory assumes that the manner in which the individual defines success and judges competence explains motivated behaviors and adjustment in achievement domains, such as sport. Nicholls identified different ways in which individuals define success and gauge their levels of competence, labeling them task-involvement and ego-involvement (Nicholls, 1989). When an individual is task-involved, subjective success and competence are selfreferenced. Task-involved individuals feel successful when they improve upon previous performances, give their utmost effort, and/or learn or master a new skill. In contrast, ego involvement occurs when success and competence are judged in relation to the accomplishments of others. An ego-involved individual will, for example, feel successful when out-performing others or doing as well as others with less effort. Whereas taskinvolvement fosters positive adaptation in achievement contexts, the motivational consequences of ego-involvement are largely dependent upon outcome of the achievement-related pursuit. That is, ego-involved individuals only report positive experiences when they win, regardless of how well they have performed. Not surprisingly ego-involvement is associated with more negative psycho-behavioral adjustment in sports (e.g., greater anxiety, unsportsmanlike behavior) particularly when coupled with low perceptions of competence (Roberts, 2002; Smith et al., 2007).

Youth involved in sport tend to be more physically active on a regular basis compared to non-participants. Evidence derived from a three-day diary (Katzmarzyk and Malina, 1998) and questionnaires (Trost et al., 1997; Pfeiffer et al., 2006; Aarnio et al., 2002) indicates that sport participants are more physically active than non-participants. Accelerometry data for boys 6-12 years indicate increased time in moderate-to-vigorous physical activity on the days of sport participation (Wickel and Eisenmann, 2007). Though limited, one study suggests reduced physical inactivity, specifically less television time among youth involved in sport (Katzmarzyk and Malina, 1998).

The preceding information is derived largely from studies in the United States and Europe. Corresponding data for Latin American youth are not as readily available. The purpose of this study is to compare the characteristics of youth sports participants and non-participants resident in Mexico City. Growth and weight status, physical activity, time viewing television and playing video games, perceptions of parental sport and physical activity, and goal orientation are specifically compared in youth sport participants and non-participants 9 - 18 years of age.

\section{METHODS}

Subjects were participants in a survey of the growth status, physical activity and sport participation of school youth resident in Mexico City (Siegel et al., 201I). The total sample included 1095 youth 9-18 years of age. The project was approved by the University Committee for Research Involving Human Subjects of Michigan State University and was sponsored by the Escuela Nacional de Antropología e Historia (ENAH). The 
project was approved by authorities of the schools involved and each participant provided informed consent.

All youth were enrolled in primary (primaria), secondary (secundaria) and high school (preparatoria) schools in the Federal District at the time of the survey. Social class or socioeconomic status (SES) was estimated on the basis of school location and home location (delegación and colonía) and occupation of parents as reported by the students. With the assistance of school authorities and colleagues at ENAH, this information was used to classify the SES of each participant as low, middle and high. A similar protocol was used in another survey of physical activity of Mexico City youth, i.e., classification of SES on the basis of school attended (Hernandez et al., 1999). Allowing for limitations of method of designation, the distribution of subjects by SES was: low, 4l\%; middle, 33\%; and high, $26 \%$.

A subsample of 591 youth completed questionnaires dealing with sport participation in organized sport, which by definition implied the presence of a coach and regular practices and competitions during a season. Of these, 168 boys and 109 girls indicated current active participation in organized non-school sport, and 18 boys and 19 girls indicated current active participation in organized school sport. Of the latter, 8 boys and 5 girls participated only in school sport. Thus, they were combined with non-school participants to provide samples of 176 male and I 4 female youth sport participants. The remaining school sport participants were also involved in non-school sponsored sport. SES did not differ between participants and non-participants in youth sports among boys $\left(\chi^{2}=0.35\right.$, ns) and girls $\left(\chi^{2}=1.37\right.$, ns). Compared to the total sample (above), the subsample of sport participants and non-participants included proportionally fewer low SES youth (27\%) and more middle SES youth (48\%), while the percentage of high SES youth was similar (25\%).

At the time of the survey, 75 boys (43\%) and 45 girls (40\%) indicated participation in only one sport. The remainder indicated participation in multiple sports. The three most popular non-school sports were soccer (76\%), basketball (58\%) and swimming (48\%) for boys, and basketball (64\%), swimming (56\%), and gymnastics (43\%) for girls. Although the number was small, the corresponding school sports were swimming (78\%), basketball (6l\%), and volleyball (44\%) in boys, and basketball (68\%), swimming (47\%), and soccer (42\%) in girls.

The Physical Activity Questionnaire (PAQ) developed for Canadian youth was used to estimate physical activity over the past seven days. The PAQ has two forms, one for older children (Kowalski et al., 1997a) and another for adolescents (Kowalski et al., 1997b). The former is designed for children from fourth to eighth grades and the latter for youth from eighth to twelfth grades. The only difference between the questionnaires for older children and adolescents is an item about activity during recess for children. The Mexican school system has a 30-minute recess period in primary schools and a 20-minute 
period in secondary schools. Given the age of the sample and recess periods in both primary and secondary schools, the PAQ form for adolescents was used.

The PAQ required the student to recall activities over the past seven days, which was consistent with evidence suggesting that a record of seven days provided a reliable estimate of the usual pattern of physical activity in youth (Trost et al., 2000). In the PAQ, physical activities were described as sports, games or dances that make the individual breathe hard, make the legs feel tired, or make the individual sweat (Crocker et al., 1997). Specific questions included the following: frequency of participation in sport and non-sport physical activities during free time; participation in physical education; activities at lunch time (in addition to eating); activities immediately after school, during evenings, and on weekends; and an overall estimate of physical activity during free time. Items were answered on a five-point scale. The average of the scores on each item provided an estimate of overall physical activity (PAQ score) which ranged from I (low) to 5 (high). A PAQ score <3.0 was approximately equivalent to 1.5-3 METS, a score 3.03.99 indicated about 3-5 METS (moderate activity) and a score $>4.0+$ indicated about $\geq 6$ METS. In the most recent compendium, moderate activities generally ranged from 3.5 to 6 METS, while vigorous activities were > 6.0 METS (Ainsworth et al., 2000).

Test-retest correlations for the PAQ were 0.75 and 0.82 in Canadian boys and girls, respectively (Kowalski et al., 1997a). The PAQ was moderately correlated with several indicators of physical activity in Canadian youth 13-20 years (Kowalski et al., 1997b). On the other hand, correlations between the PAQ (Crocker et al., 200I) and another 7-day physical activity recall instrument and estimates of activity with Tritrac and Caltrac monitors were low, leading the authors to question the viability of mechanical recorders for assessing physical activity over extended periods. Correlations between the PAQ and accelerometry were somewhat higher in rural, urban and Old Order Mennonite Canadian youth 9-12 years (Tremblay et al., 2003), while correlations between the PAQ and overall physical activity and moderate-to-vigorous activity measured with an Actigraph monitor in youth were moderate (Janz et al., 2008). The PAQ was also relatively stable across a two-year interval between II and I 3 years of age (Janz et al., 2008).

Several items in the PAQ were not used to derive the physical activity score, but provide information on time spent viewing television and playing video games and perceived physical condition and perceived activity level compared to age and sex peers. Responses on perceived physical activity and fitness compared to peers provided an estimate of convergent validity of the PAQ (Kowalski et al., 1997a, 1997b). Perceived physical activity included five options compared to peers of the same age and sex: very inactive, less active, just as active, a little more active, or much more active. Perceived fitness (physical condition) included three options compared to peers of the same age and sex: less fit, more fit, or very fit compared to others. A question asking the student to classify his/her parents as not-active or active in sport/physical activity was also included. Since parental activity was reported by the child, it was labeled 'perceived sport/activity status of the parents'. 
The PAQ was translated into Spanish and field tested in a pilot survey of approximately 100 children 9-12 years of age from three schools in middle to high SES neighborhoods. Changes were made as needed without altering the essence of the PAQ. The Spanish translation of the PAQ was subsequently finalized and administered to the survey sample in the classroom setting. Specific procedures were explained by a member of the research team to the students. The research assistant remained in the classroom while the students completed the PAQ; he/she also answered questions as necessary, and checked each questionnaire for completeness.

Height and weight of each participant were measured; the BMI was calculated. Children were classified as thin, normal weight, overweight or obese using international criteria (Cole et al., 2000, 2007). The criteria for thinness approximated two standard deviations below age- and sex-specific reference means and the $\mathrm{WHO}$ criterion for grade 2 thinness in adults $\left(\mathrm{BMl}<17.0 \mathrm{~kg} / \mathrm{m}^{2}\right)$. The term thinness was used, as the terms wasting and underweight are often confusing (Cole et al., 2007). Three boys, all sport participants, were classified as thin (low BMl for age), two 12 years and one 16 years of age. Given the ages, it is possible that the thinness of the subjects could reflect late timing of the adolescent growth spurt (Malina et al., 2004). Given the small number, they were included with normal weight boys.

The Task and Ego Orientation in Sport Questionnaire (TEOSQ, Duda, 1992) was also translated into Spanish and administered to the non-school sport participants. The TEOSQ was completed by 103 boys ( 30 non-participants and 73 sport participants) and 66 girls (23 non-participants and 43 sport participants) 14- 18 years of age.

Descriptive statistics for age, height, weight, BMI, PAQ scores, television time, video game time, and total screen time (combined television and video game) were calculated by age group and sex for youth sport participants and non-participants in two age groups, 9-13 years and $14-18$ years, as this division generally mirrored the age ranges and cutoffs between primary school and high school. The TEOSQ, as noted, was limited to youth 14-18 years. MANOVA was used to compare participants and non-participants by age group within sex. Bonferroni adjustments for multiple comparisons were used. If age differed significantly between participants and non-participants, MANCOVA, with age as the covariate, was used. Distributions of participants by weight status (normal, overweight, obese), perceived physical activity and fitness compared to age and sex peers, and perceived physical activity/sport status of adults were compared with Chi square. A significance level of $p<0.05$ was accepted, though with small sample sizes in some comparisons, marginal $p$ levels were noted. 


\section{RESULTS}

Comparisons of body size and weight status are summarized in Table I. Male sport participants are, on average, taller than non-participants in the two age groups. The difference is significant only among older youth. Age and body size do not differ between female sport participants and non-participants. The distributions of sport participants and non-participants by weight status do not differ in either sex.

Table I. Age, body size and weight status of youth sport participants and nonparticipants $9-13$ and $14-18$ years of age.

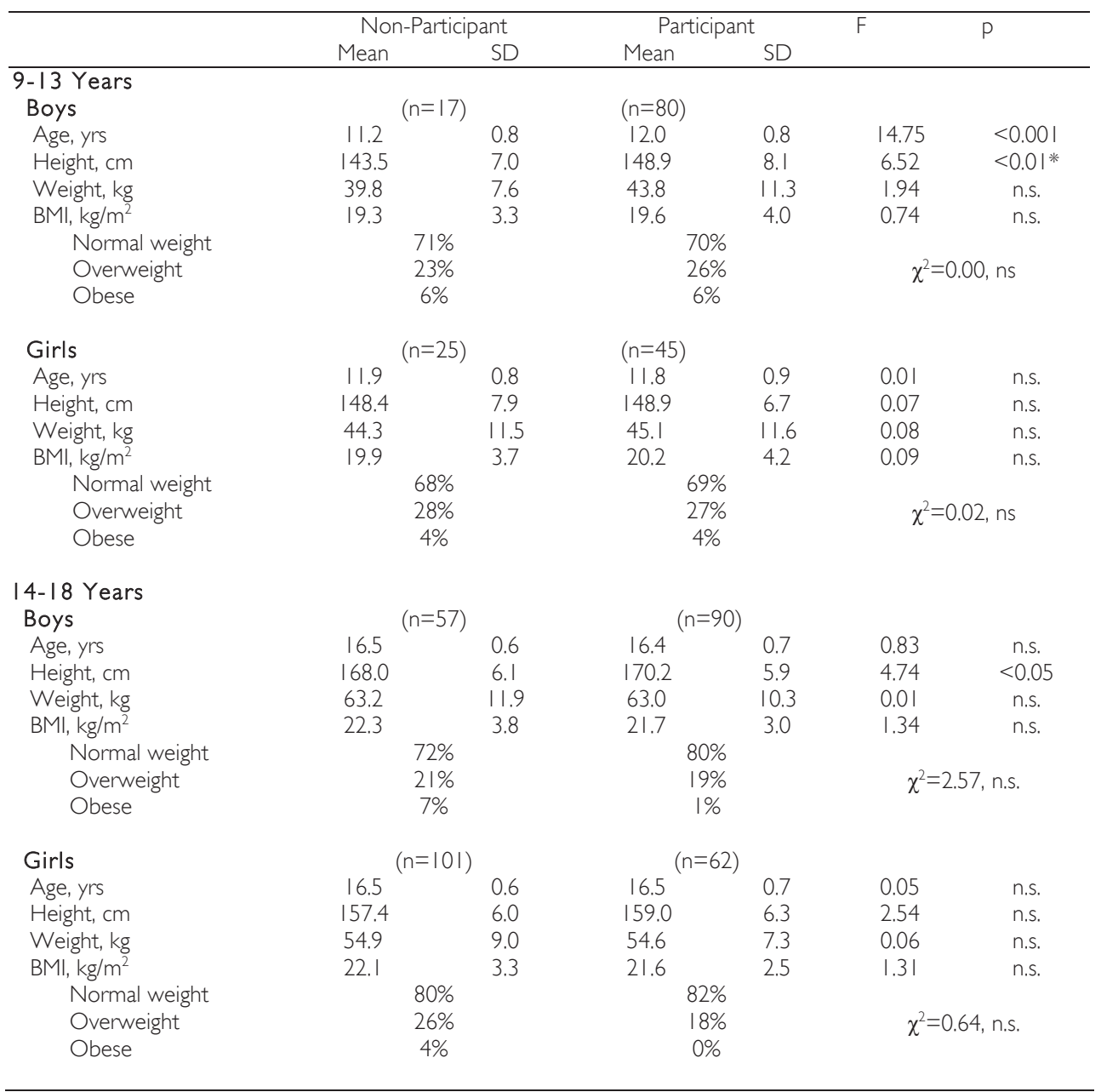

*After adjusting for age, the difference in height is not significant. 
In contrast to body size, sport participants of both sexes have, on average, higher PAQ scores than non-participants (Tables $2 \mathrm{a}$ and $2 \mathrm{~b}$ ). Perceived physical activity relative to peers does not differ between male sport participants and non-participants in both age groups, but older boys involved in sport perceive themselves as more physically fit compared to those not involved in sport. In contrast, girls in both age groups who are active in sport perceive themselves as more physically active and fit relative to peers not active in sport.

Table 2a. Age, physical activity (PAQ) and perceived physical activity (PPA) and fitness (PPF) compared to age and sex peers of youth sport participants and nonparticipants $9-13$ years.

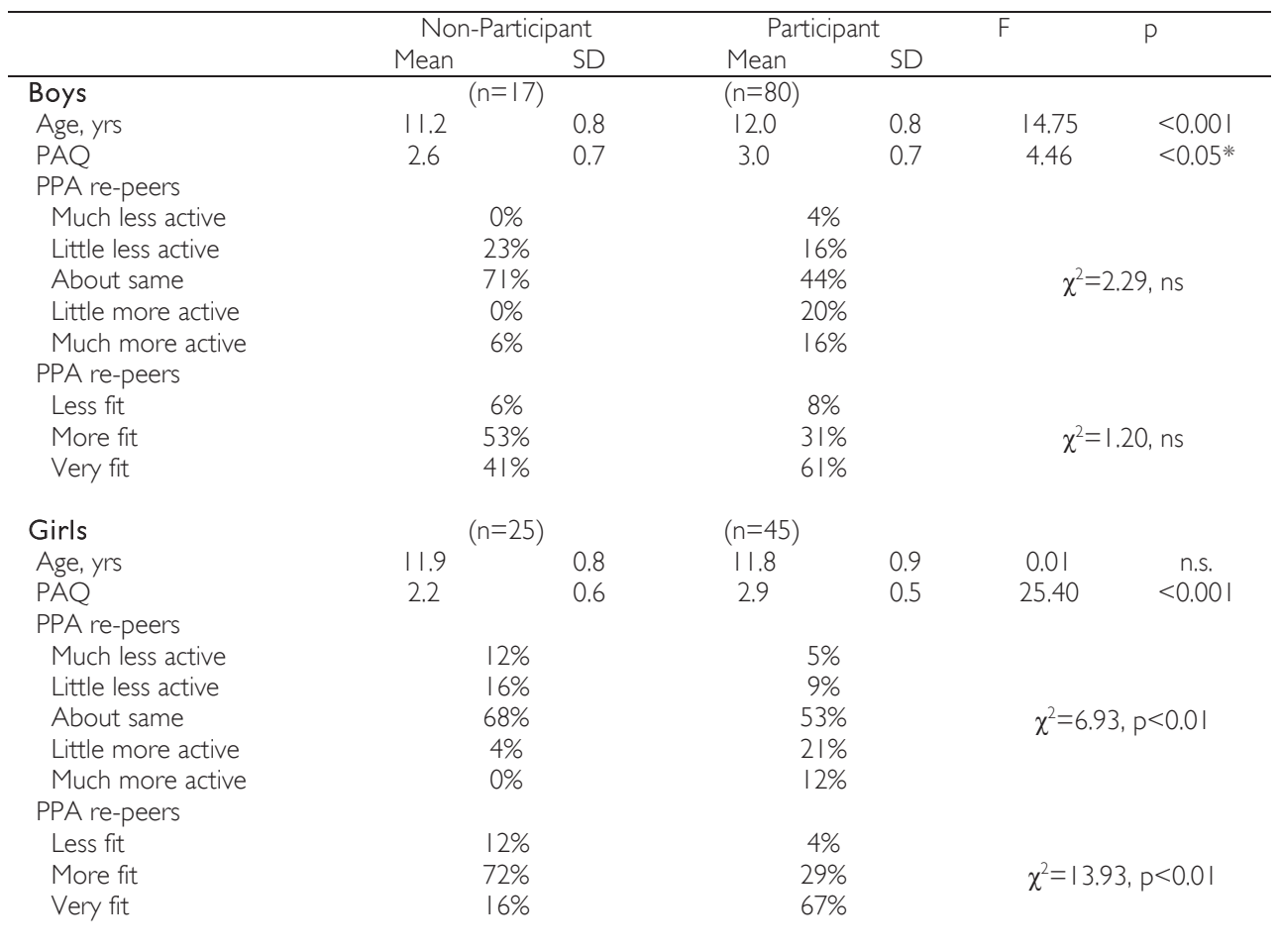

*After adjusting for age, the difference in PAQ is not significant. 
Table 2b. Age, physical activity (PAQ) and perceived physical activity (PPA) and fitness (PPF) compared to age and sex peers of youth sport participants and non-participants $14-18$ years.

\begin{tabular}{|c|c|c|c|c|c|c|}
\hline & \multicolumn{2}{|c|}{ Non-Participant } & \multicolumn{2}{|c|}{ Participant } & \multirow[t]{2}{*}{$\mathrm{F}$} & \multirow[t]{2}{*}{$P$} \\
\hline & Mean & SD & Mean & SD & & \\
\hline Boys & \multicolumn{2}{|c|}{$(n=59)$} & \multicolumn{2}{|c|}{$(n=95)$} & & \\
\hline Age, yrs & 16.5 & 0.6 & 16.4 & 0.7 & 0.83 & n.s. \\
\hline PAQ & 2.3 & 0.7 & 2.7 & 0.7 & 11.66 & $<0.01$ \\
\hline \multicolumn{7}{|l|}{ PPA re-peers } \\
\hline Much less active & \multicolumn{2}{|c|}{$8 \%$} & \multicolumn{2}{|c|}{$12 \%$} & \multirow{5}{*}{\multicolumn{2}{|c|}{$\chi^{2}=1.32, \mathrm{~ns}$}} \\
\hline Little less active & \multicolumn{2}{|c|}{$22 \%$} & \multicolumn{2}{|c|}{$16 \%$} & & \\
\hline About same & \multicolumn{2}{|c|}{$44 \%$} & \multicolumn{2}{|c|}{$34 \%$} & & \\
\hline Little more active & \multicolumn{2}{|c|}{$24 \%$} & \multicolumn{2}{|c|}{$29 \%$} & & \\
\hline Much more active & \multicolumn{2}{|c|}{$2 \%$} & \multicolumn{2}{|c|}{$10 \%$} & & \\
\hline \multicolumn{7}{|l|}{ PPA re-peers } \\
\hline Less fit & \multicolumn{2}{|c|}{$5 \%$} & \multicolumn{2}{|c|}{$2 \%$} & \multirow{3}{*}{\multicolumn{2}{|c|}{$\chi^{2}=7.99, p<0.01$}} \\
\hline More fit & \multirow{2}{*}{\multicolumn{2}{|c|}{$\begin{array}{l}59 \% \\
36 \%\end{array}$}} & \multicolumn{2}{|c|}{$39 \%$} & & \\
\hline Very fit & & & \multicolumn{2}{|c|}{$59 \%$} & & \\
\hline Girls & \multicolumn{2}{|c|}{$(n=105)$} & \multicolumn{2}{|c|}{$(n=68)$} & & \\
\hline Age, yrs & 16.5 & 0.6 & 16.5 & 0.7 & 0.05 & n.s. \\
\hline PAQ & 2.0 & 0.6 & 2.5 & 0.7 & 24.99 & $<0.001$ \\
\hline \multicolumn{7}{|l|}{ PPA re-peers } \\
\hline Much less active & \multicolumn{2}{|c|}{$13 \%$} & \multicolumn{2}{|c|}{$4 \%$} & & \\
\hline Little less active & \multicolumn{2}{|c|}{$33 \%$} & & & & \\
\hline About same & & & & & $\chi^{2}=11$ & $0<0.001$ \\
\hline Little more active & & & & & & \\
\hline Much more active & & & & & & \\
\hline PPA re-peers & & & & & & \\
\hline Less fit & & & & & & \\
\hline More fit & & & & & $\chi^{2}=6$ & $0<0.01$ \\
\hline Very fit & & & & & & \\
\hline
\end{tabular}

Television and video game time do not differ between sport participants and nonparticipants in either sex, but with the exception of boys 9-13 years, youth spend considerably more time viewing television than playing video games. Among boys 9-13 years, means for time viewing television are $2.8 \pm 2.4$ and $3.2 \pm 2.3$ hours in non-participants and sport participants, respectively. Among boys 14-18 years, corresponding means are $2.7 \pm 2.3$ and $3.0 \pm 2.2$ hours, respectively. Among girls $9-13$ years, means for time viewing television are $3.4 \pm 1.6$ and $2.7 \pm 2.1$ hours in non-participants and sport participants, respectively; corresponding means are $2.5 \pm 1.9$ and $2.4 \pm 1.7$ hours, respectively, among girls 14-18 years.

Perceptions of parental physical activity and sport do not differ between sport participants and non-participants (not shown), although proportionally more sport participants $9-13$ years perceive their fathers as active $(p=0.07)$. 
Among youth 14-18 years, male sport participants and non-participants do not differ in goal orientation, while female non-participants reported a higher ego orientation score than sport participants (Tables $3 \mathrm{a}$ and 3b). Among sport participants | 4 - 18 years, males reported a higher mean value for ego orientation $(p<0.05)$ than females, while task orientation scores do not differ (Table $4 \mathrm{a}$ ). On the other hand, among non-sport participants, females have higher task $(p<0.05)$ and ego $(p=0.07)$ orientation scores than males (Table 4b).

Table 3a. Goal orientation of youth sport participants and non-participants $14-$ 18 years in boys.

\begin{tabular}{lcccccc}
\hline & \multicolumn{2}{c}{$\begin{array}{c}\text { Non-Participants } \\
(n=30)\end{array}$} & \multicolumn{2}{c}{$\begin{array}{c}\text { Participants } \\
(n=73)\end{array}$} & & \\
& Mean & SD & Mean & SD & & \\
\hline Age, yrs & 16.4 & 0.6 & 16.5 & 0.7 & 0.41 & $n$ s \\
Task & 3.7 & 0.9 & 3.9 & 0.7 & 2.79 & ns \\
Ego & 2.5 & 0.8 & 2.8 & 0.9 & 1.28 & ns \\
\hline
\end{tabular}

Table 3b. Goal orientation of youth sport participants and non-participants $14-18$ years in girls.

\begin{tabular}{lcccccc}
\hline & \multicolumn{2}{c}{$\begin{array}{c}\text { Non-Participants } \\
(n=23)\end{array}$} & \multicolumn{2}{c}{$\begin{array}{c}\text { Participants } \\
(n=43)\end{array}$} & $F$ & $P$ \\
& Mean & SD & Mean & SD & & \\
\hline Age, yrs & 16.6 & 0.6 & 16.6 & 0.7 & 0.00 & ns \\
Task & 4.2 & 0.7 & 4.0 & 0.7 & 0.57 & ns \\
Ego & 3.0 & 0.9 & 2.4 & 0.7 & 9.54 & $<0.01$ \\
\hline
\end{tabular}

Table $4 \mathrm{a}$. Goal orientation of youth sport participants 14 - 18 years by sex.

\begin{tabular}{lcccccc}
\hline & \multicolumn{2}{c}{$\begin{array}{c}\text { Males } \\
(\mathrm{n}=73)\end{array}$} & \multicolumn{2}{c}{$\begin{array}{c}\text { Females } \\
(\mathrm{n}=43)\end{array}$} & & $\mathrm{F}$ \\
& Mean & SD & Mean & SD & & \\
\hline Age, yrs & 16.5 & 0.7 & 16.6 & 0.7 & 1.00 & $\mathrm{~ns}$ \\
Task & 3.9 & 0.7 & 4.0 & 0.7 & 0.67 & $\mathrm{~ns}$ \\
Ego & 2.8 & 0.9 & 2.4 & 0.7 & 5.85 & $<0.05$ \\
\hline
\end{tabular}


Table 4b. Goal orientation of youth sport non-participants 14 - 18 years by sex.

\begin{tabular}{lcccccc}
\hline & \multicolumn{2}{c}{$\begin{array}{c}\text { Males } \\
(n=30)\end{array}$} & \multicolumn{2}{c}{$\begin{array}{c}\text { Females } \\
(n=23)\end{array}$} & & \\
& Mean & SD & Mean & SD & & \\
\hline Age, yrs & 16.4 & 0.6 & 16.6 & 0.6 & 2.08 & ns \\
Task & 3.7 & 0.9 & 4.2 & 0.7 & 5.34 & $<0.05$ \\
Ego & 2.5 & 0.8 & 3.0 & 0.9 & 3.34 & 0.07 \\
\hline
\end{tabular}

\section{DISCUSSION}

Of the 59I (292 males, 299 females) students 9-18 years who completed the sport participation questionnaires, $58 \%$ of males and $36 \%$ of females indicated participation in organized sport (school or non-school sponsored). These values are comparatively higher than those reported for US youth of a similar age range. A survey of United States youth $10-18$ years showed percentages of sport participants of $40 \%$ and $22 \%$ for males and females, respectively (Ewing and Seefeldt, 1988; 1996). In a study of mid-Michigan middle school students, 30\% of males and 29\% of females reported participation in organized sport in mid-winter (Katzmarzyk and Malina, 1998). The prevalence of sport participation in the current study was higher than those previously reported in the literature, and males had a higher prevalence of participation than females. While the percentages of the Mexican males and females who participated in sport were seemingly high, sample size or definition of organized sport perhaps accounted for some of the variation. Both school and non-school sponsored sports were combined in the estimates. It was possible that some boys, and possibly some girls, included "pick-up" games in their responses, despite the requirement in the survey that a coach needed to be present to qualify the activity as an organized sport. If this was the case, then the responses of participants versus nonparticipants may, in fact, be more accurate than was first believed. That is, the respondents who participated in sport in all forms may be represented, rather than just those who had a coach and regular practice. If this was the case, however, the applicability of this survey to other estimates of sport participation has a limitation.

A shortcoming of the present study was the lack of a question regarding selforganized sport participation. Soccer, or fútbol, in Latin America has long been a street game that children just pick up and play when they have free time, and they often play every day, or at least on a regular basis. By not assessing this type of sport activity, information may be lacking on true levels of participation in sport. In addition, basketball now has a more informal component in Mexico for both males and females, as does volleyball for females. If the subjects did indeed count these self-organized games in their list of sports, then the prevalence of sport participation may not be so out of line with prior reports. Nevertheless, this interpretation does beg the question of how many 
Mexican youth participate in organized sport with regular practices, games or competitions, and a coach or trainer.

The higher percentages of participation in organized sport in Mexico City youth compared to United States youth, but relatively low levels of physical activity (especially in the older males and females) as estimated by the PAQ-A, also begs the following questions: To what extent does sport participation contribute to general physical activity levels in Mexican youth? How active are Mexican youth when they participate in sport? Does participation in sport entail regular involvement in exercise and conditioning? Does it involve both competition and practice? What are the frequency, intensity and duration of training? None of these questions were really addressed with the instruments used in the study. Similar questions arise with American youth, and energy expenditure is rarely documented. In a study of mid-Michigan youth 12-14 years of age, the percentage of estimated total daily energy expenditure attributed to participation in organized sport was $20 \%$ for males and $16 \%$ for females. The percentage of energy expenditure in moderateto-vigorous activity which was attributed to youth sport participation was 55\% and 65\% for males and females, respectively (Katzmarzyk and Malina, 1998). Thus, youth who participated in organized sport expended more energy in physical activity than youth who did not participate in organized sport. Therefore, if urban Mexican youth are similar to mid-Michigan youth, the amount of energy expended by sport participants may be greater than that expended by non-sport participants. As Mexican youth who participate in sport have significantly higher PAQ scores than non-participants, the current data appear to support this idea.

The comparison of the mean values of ego and task orientation across sex and participants/non-participants is of interest. In males, participants in the current study reported marginally higher levels for task and ego orientation compared to nonparticipants, though not at a statistically significant level. In females, participants and nonparticipants did not differ significantly in terms of task-orientation; however, nonparticipants reported significantly higher perceptions of ego-orientation. As noted previously, high levels of ego-orientation couple with low perceptions of competence predicts negative adaptation in achievement contexts. It is possible that low levels of egoorientation may be especially protective of sport participation in adolescent Mexican females. In support of this contention, female participants reported significant lower levels of ego orientation that male participants; whereas female non-participants reported slightly higher levels of ego orientation than their male peers. In light of these observations, future researchers should further consider the role of achievement goals, competence, and the motivational climate in relation to Mexican adolescents involvement in sports and physical activity. It is possible that an overemphasis on competition and interpersonal comparison may have a debilitating effect upon the involvement of Mexican adolescent females engagement in sports and other achievement related forms of physical activity.

Urban Mexican school age females in this study were perhaps less likely to be sport participants, which reflected cultural expectations and patterns. In the not too distant past, adolescent Mexican girls, especially those from rural communities, were 
expected to devote themselves primarily to household chores (Lewis, 1960). In a field survey from 2000-2002, required daily household activities of rural indigenous girls 9-17 years were related largely to food preparation, cleaning and washing (Malina et al., 2008). While this is no longer the case for most urban Mexican girls, the 15th birthday (quinceañera) of Mexican girls is still of particular importance in the culture as a representation of the transition from child to adult status.

In addition, adolescents in many countries, both male and female, have lower levels of physical activity than pre-adolescents (Reynolds et al., 1990; Pate et al., 1994; Malina, $200 \mathrm{la}, 200 \mathrm{lb}$ ). There is a negative association between physical activity and age in adolescent females and males (Aaron et al., 1993; Ewing and Seefeldt, 1988; Andersen et al., 1998), and results of the current study are consistent. While females are less active than males in both age groups used in this study of urban Mexican youth, the relative decline with age appears similar, and also appears less extreme in sport participants versus non-sport participants.

In summary, urban Mexican youth of both sexes involved in sport have, on average, higher levels of physical activity than youth not involved in sport. In addition, perceived physical activity and fitness relative to peers does not differ between boys involved and not involved in sport, whereas girls active in sport perceive themselves as more physically active and fit relative to their peers.

\section{ACKNOWLEDGMENT}

This research was supported in part by a grant to Robert M. Malina from the International Education Program at Michigan State University, East Lansing, MI.

\section{REFERENCES}

Aarnio, M., Winter, T., Peltonen, J., Kujala, U.M., Kaprio, J., 2002, Stability of leisure-time physical activity during adolescence-a longitudinal study among 16-, 17- and 18year-old Finnish youth. Scandinavian Journal of Medicine and Science in Sports, 12. pp. $179-185$.

Aaron, D.J., Kriska, A.M., Dearwater, S.R., Anderson, R.L., Olsen, T., Cauley, J.A., Laporte, R.E., 1993, The epidemiology of leisure physical activity in an adolescent population. Medicine and Science in Sports and Exercise, 25, pp. 847-853.

Ainsworth, B.E., Haskell, W.L., Whitt, M.C., Irwin, M.L., Swartz, A.M., Strath, S.J., O'Brien, W.L., Bassett, D.R., Schmitz, K.H., Emplaincourt, P.O., Jacobs, D.R., Leon, A.S., 2000, Compendium of physical activities: An update of activity codes and MET intensities. Medicine and Science in Sports and Exercise, 32 (suppl), pp. S498-S5I6. 
Andersen, R.E., Crespo, C.J., Bartlett, S.J., Cheskin, L.J., Pratt, M., 1998, Relationship of physical activity and television watching with body weight and level of fatness among children. Results from NHANES III. Journal of the American Medical Association, 279, pp. 938-942.

Cole, T.J., Bellizzi, M.C., Flegal, K.M., Dietz, W.H., 2000, Establishing a standard definition for child overweight and obesity worldwide: international survey. British Medical Journal, 320, pp. 1240-1243.

Cole, T.J., Flegal, K.M., Nicholls, D., Jackson, A.A., 2007, Body mass index cut-offs to define thinness in children and adolescents: international survey. British Medical Journal, 335, pp. 194-197.

Crocker, P.R.E., Bailey, D.A., Faulkner, R.A., Kowalski, K.C., McGrath, R., I997, Measuring general levels of physical activity: Preliminary evidence for the Physical Activity Questionnaire for Older Children. Medicine and Science in Sports and Exercise, 29, pp. | 344- 1349.

Crocker, P.R.E., Holowachuk, D.R., Kowalski, K.C., 200I, Feasibility of using the Tritrac motion sensor over a 7-day trial with older children. Pediatric Exercise Science, I 3 , pp. 70-81.

Duda, J.L., 1992, Motivation in sports settings: A goal perspective approach. In Motivation in Sport and Exercise, edited by Roberts, G. (Champaign, IL: Human Kinetics), pp. 57-91.

Ewing, M.E., Seefeldt, V., 1988, Participation and Attrition Patterns in American AgencySponsored and Interscholastic Sports - An Executive Summary. (East Lansing, Ml: Michigan State University, Institute for the Study of Youth Sports).

Ewing, M.E., Seefeldt, V., 1996, Patterns of participation and attrition in American agencysponsored youth sports. In Children and Youth in Sport: A Biopsychosocial Perspective, edited by Smoll, F.L. and Smith, R.E. (Madison: Brown and Benchmark), pp. $31-45$.

Gould, D., Dieffenbach, K., 2003, Psychological issues in youth sports: competitive anxiety, overtraining, and burnout. In Youth Sports: Perspectives for a New Century, edited by Malina, R.M. and Clark, M.A. (Monterey, CA, Coaches Choice), pp. I49- 170.

Hernández, B., Gortmaker, S.L., Colditz, G.A., Peterson, K.E., Laird, N.M., Parra-Cabrera, S., 1999, Association of obesity with physical activity, television programs and other forms of video viewing among children in Mexico City. International Journal of Obesity, 23, pp. 845-854.

Janz, K.F., Lutuchy, E.M., Wenthe, P., Levy., S.M., 2008, Measuring activity in children and adolescents using self-report: PAQ-C AND PAQ-A. Medicine and Science in Sports and Exercise, 40, pp. 767-772.

Katzmarzyk, P.T., Malina, R.M., 1998, Contributions of organized sports participation to estimated daily energy expenditure in youth. Pediatric Exercise Science, I0, pp. 378386.

Kowalski, K.C., Crocker, P.R.E., Faulkner, R.A., 1997a, Validation of the Physical Activity Questionnaire for older children. Pediatric Exercise Science, 9, pp. 174- 186.

Kowalski, K.C., Crocker, P.R.E., Kowalski, N.P., 1997b, Convergent validity of the Physical Activity Questionnaire for adolescents. Pediatric Exercise Science, 9, pp. 342-352. 
Lewis, O., 1960, Tepoztlán, Village in Mexico. (NY: Holt, Rinehart and Winston), pp. 7778.

Malina, R.M., 200 Ia, Physical activity and fitness: Pathways from childhood to adulthood. American Journal of Human Biology, I3, pp. 162-172.

Malina, R.M., 200lb, Tracking of physical activity across the lifespan. Research Digest, President's Council on Physical Fitness and Sports Series 3, 14, pp. I-8.

Malina, R.M., 2008, Biocultural factors in developing physical activity levels. In Youth Physical Activity and Sedentary Behavior: Challenges and Solutions, edited by Smith, A.L., Biddle, S.J.H. (Champaign, IL: Human Kinetics), pp. I4I - 166.

Malina, R.M., 2009, Children and adolescents in the sport culture: The overwhelming majority to the select few. Journal of Exercise Science and Fitness, 7, pp. SI-SIO.

Malina, R.M., Bouchard, C, Bar-Or, O., 2004, Growth, Maturation, and Physical Activity, $2^{\text {nd }}$ ed. (Champaign, IL: Human Kinetics).

Malina, R.M., Peña Reyes, M.E., Tan, S.K., Little, B.N., 2008, Physical activity in youth from a subsistence agriculture community in the Valley of Oaxaca, southern Mexico. Applied Physiology, Nutrition and Metabolism, 33, pp. 819-830.

Nicholls, J.G., 1984, Achievement Motivation: Conception of ability, subjective experience, master choice, and performance. Psychological Review, 91, pp. 328-346.

Nicholls, J.G., 1989, The Competitive Ethos and Democratic Education. (Cambridge, MA: Harvard University Press.)

Pate, R.R., Long, B.J., Heath, G., 1994, Descriptive epidemiology of physical activity in adolescents. Pediatric Exercise Science, 6, pp. 434-447.

Pfeiffer, K.A., Dowda, M., Dishman, R.K., Mclver, K.L., Sirard, J.R., Ward, D.S., Pate, R.R., 2006, Sport participation and physical activity in adolescent females across a four year period. Journal of Adolescent Health, 39, pp. 523-529.

Physical Activity Guidelines Committee, 2008, Physical Activity Guidelines Committee Report, Part G. Section 9. Youth. Washington, DC: Department of Health and Human Services), pp. G9-I - G9-33.

Reynolds, K.D., Killen, J.D., Bryson, S.W., Maron, D.J., Barr Taylor, C., Maccoby, N., Farquhar, J.W., 1990, Psychosocial predictors of physical activity in adolescents. Preventive Medicine, 19, pp. 54|-55।.

Roberts, G.C., 2002, Achievement goal theory: Where have we been, and where are we going? Journal of Sport and Exercise Psychology, 24, pp. 105- 105.

Siegel, S.R., Malina, R.M., Peña Reyes, M.E., Cárdenas Barahona, E.E., 20II Correlates of physical activity and inactivity in urban Mexican youth. American Journal of Human Biology, 23, pp. 686-692.

Smith, R.E., Smoll, F.L., and Cumming, S.P., 2007, Effects of a motivational climate intervention for coaches on young athletes' sport performance anxiety. Journal of Sportand Exercise Psychology, 29, pp. 39-59.

Tremblay, M.S., Barnes, J.D., Copeland, J.L., Esliger, D.W., 2005, Conquering childhood inactivity: Is the answer in the past? Medicine and Science in Sports and Exercise, 37, pp. | | 87- | 194. 
Trost, S.G., Pate, R.R., Freedson, P.S., Sallis, J.F., Taylor, W.C., 2000, Using objective physical activity measures with youth: How many days of monitoring are needed? Medicine and Science in Sports and Exercise, 32, pp. 426-431.

Trost, S.G., Pate, R.R., Saunders, R.P., Ward, D.S., Dowda, M., Felton, G., 1997, A prospective study of the determinants of physical activity in rural fifth-grade children. Preventive Medicine, 26, pp. 257-263.

Weinberg, R.S., Gould, D., 2010, Foundations of Sport and Exercise Psychology. (Champaign, IL: Human Kinetics).

Wickel, E.E., Eisenmann, J.C., 2007, Contribution of youth sport to total daily physical activity among 6- to 12-yr-old boys. Medicine and Science in Sports and Exercise, 39, pp. I493-1500. 